\title{
Growth Promotion and Bi-Control Approaches of Brown Root Rot Disease of Tea by Pseudomonas Aeruginosa (PM 105)
}

\section{P Morang ${ }^{1 *}$, BK Dutta', BS Dileep Kumar ${ }^{2}$ and MP Kashyap ${ }^{3}$}

${ }^{1}$ Microbial \& Agricultural Ecology and Biodiversity conservation Laboratory, Department of Ecology \& Environmental Science, Assam University, Silchar, Assam, India ${ }^{2}$ Agroprocessing and Natural Products Division, NIIST (CSIR), Thiruvanathapuram, Kerala, India

${ }^{3}$ Department of Business Administration, Assam University, Silchar, Assam, India

\begin{abstract}
Pseudomonas aeruginosa (PM 105) isolated from tea (Camellia sinensis) plantation soil of Barak Valley, Assam, (India) showed biocontrol and growth promotion potential against the tea root pathogen Fomes lamoensis, infested one year old tea plants under nursery condition. In the in vitro antagonism study, PM 105 showed significant inhibition in all the three media (KB, NA and PDA) tested against the pathogen, both in spot and line inoculation. In the nursery experiment, tea plants treated with $F$. lamoensis alone showed $73 \%$ disease incidence, whereas in $P$. aeruginosa along with the pathogen showed reduced percentage of disease incidence (only $33.33 \%$ ). An increase in number of new leaves (NNL), number of lateral branches (NLB), shoot height (SH) and root length (RL) was observed, following the application of the bacterial treatment. It was also observed the fresh weight of shoot (FWS), and root (FWR), dry weight of shoot (DWS), and root (DWR), chlorophyll a and b in $P$. aeruginosa treated plants, have also increased. The results indicate the biocontrol and plant growth promoting potentials of $P$. aeruginosa on tea.
\end{abstract}

Keywords: Antagonism; Bio control; Camellia sinensis; Fomes lamoensis; Plant growth promotion; Pseudomonas aeruginosa

\section{Introduction}

Tea (Camellia sinensis (L) O. Kuntze) belongs to the family Theaceae. It is a dicotyledonous perennial crop. Tea is the second largest consumed beverage in the world, after water. Total tea production of the world during 2007 was 3.527 million tones, and the total area under cultivation is around 5 million hectares [1]. Tea cultivation was initiated in India, around 1886, with the opening of few gardens under two tea companies of Assam. Barak Valley region of Assam have 35,000 hectares (approx.) area under tea cultivation, which annually produces 46,000 thousands $\mathrm{Kg}$ of tea (approx.) [2]. As it is a long duration plantation crop, it has become largely prone to be attacked by several pathogens [3]. Disease problems are found to be an integral part of the tea plant, which is under monoculture for over 150 years in North Eastern (N.E) region of India, including Barak Valley of Assam [4]. Petch describes Brown root rot disease, Fomes lamoensis, as the earliest known root disease of tea. Symptoms of brown root rot disease are: slow plant growth, yellowing and wilting of leaves, defoliation, branch dieback, and plant death. Soil represents a highly heterogenous environment for the microbiota inhabiting. Some are beneficial and some detrimental, while others may have no direct effect. Pseudomonas aeruginosea is one of the free living microorganisms, which can be considered as Plant Growth Promoting Rhizobacteria (PGPR), having the ability to colonize plants roots and stimulate growth of plants, and contributes to disease control [5-10]. Use of biological control agents such as Plant Growth Promoting Rhizobacteria (PGPR) can be a suitable approach for the biocontrol of disease $[11,12]$. This would also be an alternative to decrease the input chemical fertilizer, which is having detrimental effect on the environment [13]. Several mechanism have been involved to explain how the PGPRs stimulate plant growth, which may be either direct, e.g. production of growth hormones, phosphate solubilization, nitrogen fixation etc., or, indirect, viz., suppression of deleterious microorganisms by siderophore production, or secretion of antifungal metabolites [13]. In the present work, some observations were made on the potential of Pseudomonas aeruginosa in the growth promotion of young tea plants, and the control of tea root pathogen Fomes lamoensis under nursery condition.

\section{Materials and Methods}

\section{Study area}

Barak valley is located in southern part of Assam, which falls under $24^{\circ} 80 /$ and $25^{\circ} 80 / \mathrm{N}$ latitude and $92^{\circ} 15 /$ and $93^{\circ} 15 / \mathrm{E}$ longitude. Rainfall of this region ranges from $2500 \mathrm{~mm}$ to $4000 \mathrm{~mm}$, and temperature between $9.2^{\circ} \mathrm{C}$ to $36^{\circ} \mathrm{C}$.

\section{Collection of soil samples}

Soil samples were collected from multi location areas of Barak valley. The sites of collection selected are mainly tea plantations. The soil samples were collected in plastic bags and brought to the laboratory without sealing, and then these samples were air dried, homogenized and sieved (200 mesh) to get uniform samples.

\section{Isolation of pseudomonas aeruginosa}

Pseudomonas aeruginosa (PM 105) isolation has been done according to Cappucino and Sherman [14].

Plant material: One year old tea saplings (Clone: TV 1) were supplied by Rosekandy Tea Eastate, Barak Valley, Assam (India).

Fungal isolate: The fungal pathogen Fomes lameonsis (F. lamoensis) (culture no. 4140) is procured from Indian Type Culture Collection

*Corresponding author: P Morang, Microbial \& Agricultural Ecology and Biodiversity conservation Laboratory, Department of Ecology and Environmental Science, Assam University, Silchar, Assam, India 788011, Tel: 09864327718; E-mail: pmorangaus.009@gmail.com

Received July 21, 2012; Accepted September 10, 2012; Published September 15,2012

Citation: Morang P, Dutta BK, Dileep Kumar BS, Kashyap MP (2012) Growth Promotion and Bi-Control Approaches of Brown Root Rot Disease of Tea by Pseudomonas Aeruginosa (PM 105). J Plant Pathol Microb 3:129. doi:10.4172/2157-7471.1000129

Copyright: $\odot 2012$ Morang $P$, et al. This is an open-access article distributed under the terms of the Creative Commons Attribution License, which permits unrestricted use, distribution, and reproduction in any medium, provided the original author and source are credited. 
(ITCC) of Indian Agricultural Research Institute (IARI), New Delhi, India. The pathogen was also isolated locally from the diseased root samples of tea, collected from Roskandy Tea Estate. This isolate was verified and confirmed, comparing the isolate received from ITCC.

\section{In vitro antibiosis test with live organism}

In vitro antagonism test was done by two methods, as recommended by Dileep Kumar [15]: Spot inoculation and Line inoculation.

Spot inoculation: For this, an actively growing mycelial disc of the pathogen (approx. $4 \mathrm{~mm}^{2}$ ) was placed in the centre of the petri plate, and a loopful of the rhizobacterial strain was spot-inoculated in the periphery of the Petri plate, $2.0 \mathrm{~cm}$ inside at two opposite equidistant places and incubated at $28 \pm 2^{\circ} \mathrm{C}$. Inhibition zones were measured as distance (in $\mathrm{cm}$ ) between the respective test bacteria PM 43 (antagonist) and the fungal pathogen F. lamoensis, after 7 days growth under incubation.

Line inoculation: King's medium B (KB), Nutrient Agar (NA) and Potato Dextrose Agar (PDA), were used for examining the antagonism. For this, an actively growing mycelial disc (approx. $6 \mathrm{~mm}^{2}$ ) was placed at one side of the Petri plate, $2 \mathrm{~cm}$ inside of the periphery and a loopful of the rhizobacterial strain was streaked in a line, on the opposite side at a distance of $5 \mathrm{~cm}$ from the mycelial disc. The plates were incubated at 28 $\pm 2^{\circ} \mathrm{C}$ and inhibition zone was measured, as distance (in $\mathrm{cm}$ ) between the respective rhizobacterial strain PM 43 (antagonist) and F. lamoensis (fungal tea pathogen), after 7 days of growth under incubation.

\section{Growth promotion and disease suppression study under nursery condition}

This was done according to Dileep Kumar and Bezbaruah [16]. The experiment was laid out in Completely Randomized Design (CRD), which was three set of each replication and repeated thrice. Under each replication, 10 numbers of tea saplings were treated as per treatment. The tea plants were planted in the polythene bags $(21 \times 15 \mathrm{~cm})$, filled with a mixture of sterilized soil and Farm Yard Manure (FYM) in 3:1 ratio. Tea saplings with the treatment of $F$. lamoensis alone served as control, F. lamoensis+PM 105 and PM 105 alone, were challenge inoculated with the homogenized broth culture of the pathogen, F. lamoensis (10 days old) @50 ml/clonal plant, simultaneously bacteria grown on Nutrient broth (NB) medium (for $48 \mathrm{~h}$ ) culture were applied on the tea clonal plants, with the same quantity. Hygienic condition was maintained by weeding, light forking and irrigation, as and when required to maintain the healthy condition of the tea plants and to minimize the interference of external factors, other than desired. After a month of planting, plants were again treated twice with respective pathogen and PGPR strains, as per different treatment specifications at 15 days interval. After 60 days following treatments, five numbers of representative tea plants were selected randomly and uprooted from the polythene bags with utmost care to keep the roots intact and then, washed gently under running tap water to remove the adhering soil particles. Data on growth promotion in terms of increase in shoot height, root length, chlorophyll content of leaves, fresh and dry weight of shoot, root and number of newly emerged leaves were recorded. Disease incidence was recorded upto 90 days of treatment. Per-cent Disease Incidence (PDI) and Percent Disease Control (PDC) were calculated, based on the disease incidence. The percentage of survival of the tea plants was also recorded up to 90 days of growth, following the treatment.

\section{Assessment of the disease incidence}

Occurrence of disease symptom was observed by recording the wilting of leaf, leading to drying of the plant. Randomly 15 plants were selected from different treatments in the nursery and the number of plants that wilted were counted, and the mean wilt incidence was expressed in percentage. Disease incidence was recorded upto 90 days of treatment. The percent disease incidence was calculated, by using the following formula. Percent disease control was calculated, based on the per-cent disease incidence.

Percent disease incidence $(\mathrm{PDI})=\frac{\text { Number of plants infected }}{\text { Total number of plants observed }} \times 100$

\section{Statistical analysis}

All the data obtained were subjected to perform statistical tests of analysis of variance with least significant difference (LSD), with the help of SPSS (portable_PASW_statistics_18) software. $(\mathrm{P} \leq 0.05)$.

\section{Results}

In in vitro antibiosis test, isolated bacterial strain of Pseudomonas aeruginosa was found to show remarkable significant results against the pathogen, which was able to make a zone of inhibition in all media such as PDA, NA and King's B, both in spot and line inoculations (Figure 1). Highest zone of inhibition was observed in King's B medium with line inoculation (Table 1).

\section{Growth promotion and disease suppression study under nursery condition}

In this study, disease suppression was encountered by wilting of leaves to drying of tea plants. Hence, it is found that plants treated with only pathogen, by infesting the soil in the nursery (control) condition, showed drying of leaves (wilting), which occurred after $32^{\text {nd }}$ day onwards, whereas drying of tea plants occurred on the 78th day (Table 2). On the other hand, the treatment in which the pathogen and the bacteria were inoculated to the same tea plants, (F. lamoensis $+\mathrm{PM}$ $105)$ drying of leaf was observed after $58^{\text {th }}$ day. There was no record of plants drying, and no symptoms were found in tea plants treated with bacterium only (PM 105), which remained healthy upto the last day $\left(90^{\text {th }}\right.$ day) of observation.

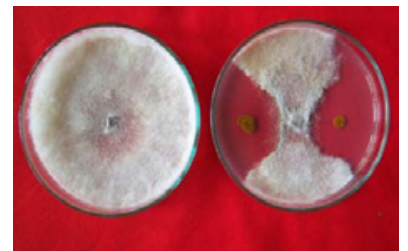

(A)

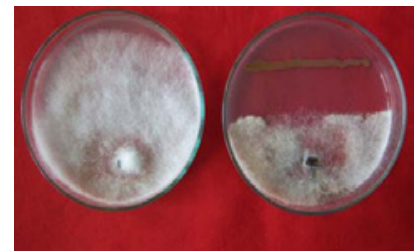

(B)
Figure 1: In vitro antagonism study of Pseudomonas aeruginosa against $F$. lamoensis (spot and line inoculation).

(A) Spot inoculation and (B) Line inoculation

\begin{tabular}{|l|l|l|l|}
\hline Strain & Media & \multicolumn{2}{l|}{ Zone of inhibition (in cm) } \\
\hline $\begin{array}{l}\text { Pseudomonas } \\
\text { aeruginosa (PM 105) }\end{array}$ & King's B (KB) & $1.25 \pm 1.73$ & $1.57 \pm 0.57$ \\
\hline & Nutrient Agar (NA) & $1.20 \pm 0.65$ & $1.43 \pm 0.57$ \\
\hline & $\begin{array}{l}\text { Potato dextrose Agar } \\
\text { (PDA) }\end{array}$ & $1.11 \pm 0.57$ & $1.14 \pm 1.00$ \\
\hline Control & KB, NA and PDA & $0.00 \pm 0.00$ & $0.00 \pm 0.00$ \\
\hline
\end{tabular}

At $\mathrm{P}_{0.05}$ Pseudomonas aeruginosa have significant inhibition over control. *Values are mean \pm Sd from five set each

Table 1: In vitro antagonism of $P$ seudomonas aeruginosa against $F$. lamoensis (Spot and Line inoculation). 
Citation: Morang P, Dutta BK, Dileep Kumar BS, Kashyap MP (2012) Growth Promotion and Bi-Control Approaches of Brown Root Rot Disease of Tea by Pseudomonas Aeruginosa (PM 105). J Plant Pathol Microb 3:129. doi:10.4172/2157-7471.1000129

Page 3 of 4

\begin{tabular}{|c|c|c|c|c|c|c|c|}
\hline \multirow[t]{2}{*}{ Treatments } & \multicolumn{3}{|c|}{ Drying of leaves } & \multicolumn{3}{|c|}{ Leaf shedding } & \multirow[t]{2}{*}{ Drying of tea plants } \\
\hline & 1 leaf & 2 leaf & More than 2 leaf & 1 leaf & 2 leaf & More than 2 leaf & \\
\hline Fomes lamoensis alone & $32^{\text {nd }}$ day & $40^{\text {th }}$ day & $56^{\text {th }}$ day & $36^{\text {th }}$ day & $47^{\text {th }}$ day & $49^{\text {th }}$ day & $78^{\text {th }}$ day \\
\hline PM 105 & - & - & - & - & - & - & - \\
\hline PM 105 + F. lamoensis & $58^{\text {th }}$ day & $62^{\text {nd }}$ day & $69^{\text {th }}$ day & $62^{\text {nd }}$ day & $65^{\text {th }}$ day & - & - \\
\hline
\end{tabular}

Table 2: Occurrence of drying symptoms in tea plants under nursery condition.

\begin{tabular}{|c|c|c|c|c|c|c|c|c|c|c|}
\hline Treatment & NNL & NLB & $\mathrm{SH}(\mathrm{cm})$ & $\mathrm{RL}$ (cm) & FWS (gm.) & FWR (gm.) & DWS (gm.) & DWR (gm.) & $\mathrm{CHL}$ a & CHL b \\
\hline $\begin{array}{l}\text { Fomes lamoensis } \\
\text { (Control) }\end{array}$ & $2.2 \pm 0.59$ & $1.4 \pm 0.26$ & $18.51 \pm 1.07$ & $16.18 \pm 0.96$ & $0.81 \pm 0.04$ & $1.42 \pm 0.07$ & $0.33 \pm 0.01$ & $0.48 \pm 0.02$ & $1.36 \pm 0.11$ & $0.63 \pm 0.03$ \\
\hline $\begin{array}{l}\text { PM 105+ Fomes } \\
\text { lamoensis }\end{array}$ & $\begin{array}{l}5.8 \pm 0.81^{*} \\
(163.63)\end{array}$ & $\begin{array}{l}3.9 \pm 0.78 \\
(178.57)\end{array}$ & $\begin{array}{l}31.1 \pm 1.26^{*} \\
(68.01)\end{array}$ & $\begin{array}{l}25.21 \pm 1.55^{\star *} \\
(55.81)\end{array}$ & $\begin{array}{l}2.31 \pm 0.08^{*} \\
(182.76)\end{array}$ & $\begin{array}{l}2.80 \pm 0.41^{*} \\
(97.18)\end{array}$ & $\begin{array}{l}0.88 \pm 0.03^{* *} \\
(166.66)\end{array}$ & $\begin{array}{l}1.11 \pm 0.20^{*} \\
(131.25)\end{array}$ & $1.73 \pm 0.16$ & $0.94 \pm 0.03^{*}$ \\
\hline PM 105 & $\begin{array}{l}5.2 \pm 0.95^{*} \\
(136.36)\end{array}$ & $\begin{array}{l}4.4 \pm 0.58^{*} \\
(214.28)\end{array}$ & $\begin{array}{l}32.43 \pm 1.07^{*} \\
(75.29)\end{array}$ & $\begin{array}{l}26.43 \pm 1.80^{* *} \\
(63.34)\end{array}$ & $\begin{array}{l}2.35 \pm 0.12^{*} \\
(190.12)\end{array}$ & $\begin{array}{l}2.69 \pm 0.36 \\
(89.43)\end{array}$ & $\begin{array}{l}0.89 \pm 0.05^{\star *} \\
(171.51)\end{array}$ & $\begin{array}{l}1.00 \pm 0.14^{*} \\
(108.95)\end{array}$ & $1.90 \pm .00^{*}$ & $0.12 \pm 0.06^{* *}$ \\
\hline LSD at $5 \%$ level & 1.76 & 1.36 & 2.43 & 3.11 & 0.67 & 0.92 & 0.65 & 0.71 & 0.78 & 0.77 \\
\hline
\end{tabular}

“*'indicates significant at $\mathrm{P}_{0.05}$ level and ‘**'significant at $\mathrm{P}_{0.01}$ level. Values are Mean $\pm \mathrm{SE}$

$\mathrm{NNL}=$ Number of new leaves, NLB=Number of lateral branches, $\mathrm{SH}=\mathrm{Shoot}$ height, RL=Root length, FWS=Fresh weight of shoot, FWR=Fresh weight of root, DWS=Dry weight of shoot, DWR=Dry weight of root, $\mathrm{CHL}$ a $=$ Chlorophyll $\mathrm{a}, \mathrm{CHL} b=$ Chlorophyll $b$

Data within parentheses denotes percent increase over (\% IOC) control

Table 3: Effect of Pseudomonas aerugnosa on the different growth parameters of tea under nursery condition.

It was also found that Pseudomonas aeruginosa treatment has shown significant result on the different growth promotion parameters on tea, in nursery condition. The treated tea plants were observed with the increased in all growth promotion parameters, over the non treated control (F. lamoensis alone). Among the parameters, highest number of new leaves, lateral branches, shoot height, root length, fresh weight of shoot, fresh weight of root, dry weight of shoot were observed in only bacteria treated plants (PM105), followed by the treatment of pathogen in the inoculated bacterized tea plants (F. lamoensis+PM 105) (Table 3). The treatment also resulted in green leaves with high chlorophyll content, over non- treated plants (control).

Highest percent increase over control in number of lateral branches (214.28\%), shoot height (75.29\%), root length (63.34\%), fresh weight (190.12\%) and dry weight of shoot (171.51\%) were recorded in PM 105 treatments, whereas in the treatment where pathogen and PGPR both were applied, highest per cent increase over control in the number of new leaves (163.63\%), fresh weight of root $(97.18 \%)$ and dry weight of root $(131.25 \%)$ were recorded in the treatment with F. lamoensis+PM 105 (Table 3).

\section{Percent disease incidence under nursery conditions}

Under nursery condition, tea plants which were grown in soil infested with $F$. lamoensis (control) have shown $73.00 \%$ disease incidence, whereas plants treated with the pathogen and inoculated with the bacteria ( $F$. lamoensis+PM 105), the disease incidence was recorded $33.33 \%$ only, or $67.00 \%$ disease control vice-versa (Table 4 ).

\section{Discussion}

In the present study, the rhizobacterial strain Pseudomonas aeruginosa (PM 105) isolated from tea soil showed significant inhibition zone against the pathogen (Figure 1), both in spot and line inoculation method in vitro. Some PGPR's synthesize antifungal antibiotics, which inhibits growth of phytopathogenic fungi [15,17]. PGPR's are indigenous to soil and plant rhizosphere, and play a major role in the biocontrol of plant pathogens $[13,18]$. The bacterial strains have been reported to control many plant pathogens, through in vitro antibiosis study done by several workers [17-22]. Although the in vitro antibiosis test does not always correlate with the suppression of soil-borne plant disease, but because of the magnitude of the rhizosphere population and the lack of a more reliable method, in vitro screening of organism is a valuable tool to select the potential strains $[23,24]$. Exploitation of beneficial rhizobacteria for crop enhancement and disease control is relatively, a new and emerging area in agricultural biotechnology. Use of these rhizobacteria can result to physiological and chemical stimulation of the plant roots, resulting more rapid emergence, higher chlorophyll levels, and enhanced plant health $[10,25]$. Growth promotion can also depend on the suppression of either deleterious microorganisms of the soil, and rhizosphere that reduce plant growth and development of soil borne pathogens that cause diseases such as damping-off, rots and wilts [2]. Pseudomonas sp. are widespread bacteria in agricultural soil, used as PGPR [17]. Pseudomonas aeruginosa has been reported to be potential PGPR, that inhibited the growth of the pathogens on several crops $[26,27]$. Complex reciprocal interactions between soil, plant and microorganisms that occur, could also account for the population dynamics of the biocontrol agent [28]. Application of bacterial strains to the rhizosphere of tea plants for enhanced growth and productivity in terms of biomass, have been reported by some workers [18,28]. In the present nursery studies, it has been observed that the treatment with the bacterial strain PM 105 showed survival of the clonal tea plants for a longer period, whereas the fungus (pathogen) treated plants without bacterial treatment, died after $78^{\text {th }}$ day onwards after inoculation. It was also assumed that the bacteria treated tea plants grown in pathogen infested soil survived till the duration of observation, where number of new leaves, lateral branches, shoot height, root length, fresh weight of shoot and root, dry weight of shoot, dry weight of root and chlorophyll content increased. The highest disease control with reduced disease incidence was also found in F. lamoensis+PM 105 treated nursery plants.

Bacterial strain PM 105 was applied, either alone, or in combination with the pathogen under nursery condition showed remarkable performance in disease control, and in various growth and yield parameters. The consistent performance of PM 105 indicate its potential to be used as biocontrol agent and as a biofertilizer, in the case of brown root rot disease infested tea fields. This will also help in the enhancement of the growth and yield of tea in Barak valley, Assam, for the benefit of the tea industry of N.E. India in general, and of Barak Valley, in particular. 
Citation: Morang P, Dutta BK, Dileep Kumar BS, Kashyap MP (2012) Growth Promotion and Bi-Control Approaches of Brown Root Rot Disease of Tea by Pseudomonas Aeruginosa (PM 105). J Plant Pathol Microb 3:129. doi:10.4172/2157-7471.1000129

\begin{tabular}{|l|c|c|}
\hline Treatments & Disease incidence (\%) & $\begin{array}{c}\text { Percent disease } \\
\text { control }\end{array}$ \\
\hline F. lamoensis alone (Control) & 73.00 & 0.00 \\
\hline F. lamoensis+ P. aeruginosa & 33.33 & 67.00 \\
\hline P. aeruginosa & 0.00 & 0.00 \\
\hline
\end{tabular}

Table 4: Effect of different treatments on the disease incidence and percent disease control of tea plants (after 90 days).

\section{Acknowledgments}

The authors thank the University Grants Commission, New Delhi for financial assistance, to carry out the research work. Authors are also thankful to the Head Department of Ecology and Environmental Science, Assam University, Silchar, and the Director, North East Institute of Science and Technology (CSIR), Jorhat, Assam for permission to carry out the research work. We also thank Dr Suresh Korpole, Scientist Institute of Microbial Technology, Chandigarh, for the identification of the bacterial strain, for the present research work.

\section{References}

1. Saravanakumar D, Vijayakumar C, Kumar N, Samiyappan R (2007) PGPR induced defense responses in the tea plant against blister blight disease. Crop Protection 26: 556-565

2. Annonymous (2009) Statistics of Tea. Tea Board of India.

3. Saha A, Dasgupta S, Mandal P, Saha D (2005) Reduction in disease in young tea plants against Curvularia eragrostidis by biotic and abiotic elicitors. Stress Biology, Narosa Publishing House, New Delhi, India.

4. Dutta BK, Borthakur BK (1991) Some aspects of disease control in tea. In field management in Tea, Tea Research Association, Jorhat

5. Manikanda R, Saravanakumar D, Rajendran L, Raguchander T, Samiyappan R (2010) Standardization of liquid formulation of Pseudomonas fluorescens Pf for its efficacy against Fusarium wilt of tomato. Biological Control 54: 83-89.

6. Kloeppe JW, Schroth MN, Miller TD (1980) Effects of rhizosphere colonization by plant growth- promoting rhizobacteria on potato plant development and yield. Phytopathology 70: 1078-1082.

7. Kloeppe JW, Rodríguez-Kábana R, Zehnder AW, Murphy JF, Sikora E, et al. (1999) Plant root-bacterial interactions in biological control of soil borne diseases and potential extension to systemic and foliar diseases. Australas Plant Pathol 28: 21-26.

8. Weller DM (1988) Biological control of soilborne plant pathogens in the rhizosphere with bacteria. Annu Rev Phytopathol 26: 379-407.

9. Pieterse CMJ, Wees ACMV, Ton J, Pelt JAV, Loon LCV (2002) Signalling in rhizobacteria- induced systemic resistance in Arabidopsis thaliana. Plant Biology 4: 535-544.

10. Khalimi K, Suprapta DN (2011) Induction of plant resistance against Soybean Stunt virus using some formulations of Pseudomonas aeruginosa. Journal of ISSAAS 17: 98-105.

11. Kloepper JW (1993) Plant growth promoting rhizobacteria as biological contro agents. Soil microbial Ecology- Application in Agricultural and Environmental Management, Marcel Dekker, New York.

12. Schmidt CS, Agostini F, Leifert C, Killham K, Mullins CE (2004) Influence of soil temperature and matric potential on sugar beet seedling colonization and suppression of pythium damping-off by the antagonistic bacteria Pseudomonas fluorescens and Bacillus subtilis. Phytopathology 94: 351-363.

13. Ali B, Sabri AN, Hasnain S (2010) Rhizobacterial potential to alter auxin conten and growth of Vigna radiate (L.). World J Microbiol Biotechnol 26: 1379-1384.

14. Cappucino JG, Sherman N (1983) Microbiology A Laboratory Manual, AddisonWesley, California

15. Dileep Kumar BS (1998) Disease suppression and crop improvement through fluorescent pseudomonads isolated from cultivated soils. World J Microbio Biotechnol 14: 735-741.

16. Dileep Kumar BS, Bezbaruah B (1996) Antibiosis and plant growth promotion by a Pseudomonas strain isolated from soil under tea cultivation. Ind J Microbio 36: $45-48$.
17. Noori MSS, Saud HM (2012) Potential Plant Growth-Promoting Activity of Pseudomonas sp isolated from Paddy soil in Malaysia as Biocontrol Agent. J Plant Pathol Microb 3: 120

18. Karimi K, Amini J, Harighi B, Bahramnejad B (2012) Evaluation of biocontro potential of Pseudomonas and Bacillus spp. against Fusarium wilt of chickpea. Australian Journal of Crop Science 6: 695-703.

19. Chakrabaty U, Chakraborty B, Basnet M (2006) Plant growth promotion and induction of resistance in Camellia sinensis by Bacillus megaterium. J Basic Microbiol 46: 186-195

20. Dileep Kumar BS (1999) Fusarial wilt suppression and crop improvement through two rhizobacterial strains in chick pea growing in soil infested with Fusarium oxysporum f.sp. ciceris. Biology and Fertility of Soils 29: 87-91.

21. Dileep Kumar BS, Bezbaruah B (1997) Plant growth promotion and funga pest control through an antibiotic and siderophore producing fluorescent Pseudomonas strain from tea (Camellia sinensis (L) O. Kuntze) plantations. Ind J Exp Biol 35: 289-292.

22. Deka Boruhah HP, Dileep Kumar BS (2002) Biological activity of Secondary metabolites produced by a strain of Pseudomonas fluorescens. Folia Microbiologica 47: 359-363.

23. Sarmah SR, Dutta P, Begum R, Tanti AJ, Phukan I, et al. (2005) Microbial bioagents for controlling diseases of tea. Proceedings of International Symposium on Innovation in Tea Science and Sustainable Development in Tea Industry Hangzhou, China.

24. Ramadasappa S, Rai AK, Jaat RS, Singh A, Rai R (2012) Isolation and screening of phID (+) plant growth promoting rhizobacteria antagonistic to Ralstonia Solanacearum World J Microbial Biotechnol 28: 1681-1690.

25. Zheng Y, Xue QY, Xu LL, Xu Q, Lu S, et al. (2011) A screening strategy of fungal biocontrol agents towards Verticillium wilt of cotton. Biol Control 56: 209-216.

26. Cook RJ (1993) Making greater use of introduced microorganisms for biologica control of plant pathogens. Annu Rev Phytopathol 31: 53-80.

27. Datta M, Palit R, Sengupta C, Pandit MK, Banerjee S (2011) Plant growth promoting rhizobacteria enhance growth and yield of chilli (Capsicum annuum L.) under field conditions. Australian Journal of Crop Science 5: 531-536.

28. Mansoor F, Sultana V, Ehteshamul-Haque S (2007) Enhancement of biocontro potential of Pseudomonas aeroginosa and Paecilomyces lilacinus against root rot of mungbean by a medicinal plant Launaea nudicaulis L. Pakistan Journa of Botany 39: 2113-2119. 